minster Hospital, in a book entitled "Pharmacologia", which reached its third odition in 1820 and its fifth in 1822. According to Paris, the poisonous effects of arsenic were seen in horses and cows, which lose their hoofs, while the latter suffer from a cancerous affection in their rumps. Seventy years after the appearance of the fifth edition of Paris's book, Mr. Henry Butlin, surgeon to St. Bartholomew's Hospital, made elaborate investigations into the truth of Paris's statements about the carcinogenic action of arsenic on animals but without finding the smallest evidence of their truth. Later writers, such as Hueper, Nieberle, Prehl and Hofmann, refer to Paris's statements but without bringing any evidence as to the occurrence of cancer in animals being due to arsenic. Prof. Kennaway comes to the conclusion that statements such as those of Paris should be fully investigated before they become incorporated in text-books.

\section{Panamerican Sanitary Congress}

AN article in the November issue of the Boletin de la Oficina Sanitaria Panamericana states that a very high place must be given to the Panamerican Sanitary Congress, which was held in Rio de Janeiro during September 7-18, 1942. Every Republic of South America was represented, and all, with one exception, by specialists including directors and professors of hygiene and authorities on tropical medicine, venereal disease, malaria, tuberculosis, bacteriology, radiology, forensic medicine, dietetics, aerial quarantine, dermatology and public health administration in general. The United States delegation consisted of six members, that of Paraguay eight and that of Chile ten, while that of Brazil was naturally larger. The Dominion of Canada was represented for the first time. The problems discussed consisted of the role of public health in the defence of the hemispheres, followed by more or less closely connected subjects such as malaria, typhus, nutrition, plague, influenza, tuberculosis, quarantine, yellow fever, trypanosomiasis, dysentery, cancer, heart disease and sanitary engineering. Caracas, Venezuela, was selected as the site for the next Congress, which is to be held in 1946.

\section{Hospital Admissions in U.S. Rural and Urban Areas}

THe issue of Public Health Reports of October 30 contains an interesting survey by Selwyn D. Collins, principal statistician, United States Public Health Service, of variation in hospital admissions with the size of city, family income and other environmental factors. The survey is based on records for 8,758 families in 130 localities in eighteen States. Hospital rates were lower for rural than for urban areas, and were lower for small towns than for large cities. In cities the highest rates for admissions and days of hospital treatment occurred in the highest and lowest income groups, while in rural areas the lowest income group had the lowest hospital rates. The lowest income group in both urban and rural areas had the lowest average days per hospital case. Four important diseases were responsible for about half of all the admissions to hospital, namely, tonsillectomy, deliveries, appendicitis and accidents. The first three diseases tended towards higher percentages of cases admitted to hospital in the higher incomelevel. In the percentage of cases admitted to hospitals, deliveries showed the largest and most regular increases with income.

\section{Mycological Nomenclature}

Changes in the naming of a species following increased knowledge can be very confusing, but teachers and students who require a clear statement of the rules of nomenclature as they affect mycology will find it in a series of four short papers by Miss E. M. Wakefield, E. W. Mason, G. R. Bisby and J. Ramsbottom (Trans. Brit. Mycol. Soc., 25, Pt. 4, pp. 428-439; December 1942).

\section{Announcements}

OwING to the generosity of the Rockefeller Foundation which has for a third year in succession provided a grant for the purpose, the Royal Society is in a position to give some assistance to scientific societies and associations which, as a result of war conditions, are experiencing financial difficulties in the publication of scientific journals.

The University of Leeds has accepted a gift of $£ 50,000$ from Mr. Henry Ellison, to create an endowment fund for the provision of post-graduate fellowships for research in pure and applied chemistry and in physics.

AT the annual general meeting of the Society of Public Analysts and Other Analytical Chemists held on March 3, the following were elected officers and council for the coming year : President: S. Ernest Melling; Past Presidents serving on the Council: F. W. F. Arnaud, Bernard Dyer, John Evans, Edward Hinks, E. B. Hughes, G. Roche Lynch, W. H. Roberts and G. Rudd Thompson; VicePresidents: H. E. Cox, G. Hogan, T. Rendle, W. Gordon Carey (chairman, North of England Section) and A. R. Jamieson (chairman, Scottish Section); Hon. Treasurer: George Taylor; Hon. Secretary: Lewis Eynon; Other Members of Council: J. W. Corran, R. H. Ellis, J. G. A. Griffiths, D. W. KentJones, R. Lessing, H. M. Mason, B. G. MeLellan, M. Pearson, W. H. Simmons, R. W. Sutton, E. Voelcker, K. A. Williams, Arnold Lees (hon. secretary, North of England Section) and R. S. Watson (hon. secretary, Scottish Section).

A NEw editorial board of Endocrinology has been appointed as follows : J. S. L. Browne, Department of Medicine, McGill University ; E. T. Engle, Department of Anatomy, College of Physicians and Surgeons, New York; Carl G. Hartman, Department of Zoology, University of Illinois ; E. C. Kendall, Division of Biochemistry, Mayo Clinic ; F. C. Koch, Department of Biochemistry, University of Chicago ; C. N. H. Long, Department of Physical Chemistry, Yale University School of Medicine; and H. B. van Dyke, Squibb Institute for Medical Research. The managing editor is E. B. Astwood, of the Departments of Medicine and Pharmacology, Harvard Medical School; the associate managing editor is E. W. Dempsey, of the Department of Anatomy, also of Harvard Medical School.

A ReSEARCH scholarship of the value of $£ 400$ per annum and tenable for two years has been offered by the Wrought Light Alloys Development Association to encourage and facilitate research in the application of light alloys to ship construction. The scholarship will be administered by a Committee of the Institution of Naval Architects and it is hoped to make the award in September next. Full particulars of entry, which closes on July 31, can be obtained from the Secretary, Institution of Naval Architects, 10 Upper Belgrave Street, London, S.W.1. 